\title{
Indonesian Teachers' Knowledge of ICT and the Use of ICT in Secondary Mathematics Teaching
}

\author{
Mailizar Mailizar ${ }^{1 *}$, Lianghuo Fan ${ }^{2}$ \\ ${ }^{1}$ Mathematics Education Department, Universitas Syiah Kuala, Banda Aceh, INDONESIA \\ ${ }^{2}$ Asian Centre for Mathematics Education, East China Normal University, CHINA
}

Received 22 May 2019 - Revised 14 June 2019 - Accepted 28 June 2019

\begin{abstract}
Indonesia, like many other countries, see Information and Communication Technology (ICT) as a potential tool for enhancing the quality of education. However, there is a lack of research examining Indonesian secondary mathematics teachers' knowledge in the integration of ICT. In this study, we aimed to investigate Indonesian secondary teachers' knowledge in the use of ICT in secondary mathematics classrooms. The study employed a quantitative method with a cross-sectional survey approach. It was conducted in one of Indonesia's provinces where the data were collected from 341 secondary mathematics teachers through a questionnaire survey. The findings suggest that, to a large extent, Indonesian secondary mathematics teachers have a largely inadequate knowledge of ICT and knowledge of ICT use in teaching. Based on the findings, we argue that it is crucial to improve Indonesian teachers' knowledge of both aspects, and more training courses for teachers' knowledge development are needed.
\end{abstract}

Keywords: ICT, Indonesian mathematics education, teacher education, teacher knowledge

\section{INTRODUCTION}

Like many other countries in the world, the current secondary mathematics curriculum in Indonesia emphasises the use of ICT in the practice of teaching and learning. This is clearly stated in the secondary school mathematics' curriculum document, as it says "in order to improve the effectiveness of teaching and learning, schools should promote the use of information and communication technology such as computer, concrete material and other media" (MoEC, 2007, p. 397).

The Indonesian government implemented a reformed curriculum in 1984 which signalled the first attempted policy directive to integrate modern technologies into mathematics classrooms (Mailizar, Manahel and Fan, 2014). It was an example of the government's efforts to strengthen mathematics education in the country (Ruseffendi, 1988, p. 102). This indicates that the integration of modern technology in teaching and learning has been a feature for quite a long time of the mathematics curriculum in the country. In a sense, this also explains that the integration of modern technology in teaching and learning has been a feature of the Indonesian mathematics curriculum for quite a long time.

It is widely believed that teachers play a significant role in the integration of ICT in the classroom. Therefore, while earlier research on the integration of ICT has mostly focused on the students' outcome (e.g., Hennessy, Fung, \& Scanlon, 2001; Sinclair \& Jackiw, 2005; Smeets, 2005; Witte \& Rogge, 2014), more recent studies have shifted focus to teachers' development of their knowledge (Clark-Wilson, Robutti, \& Siclair, 2014). Researchers in many countries have conducted studies on teachers' knowledge of ICT or the use ICT in teaching, for example, Archambault and Crippen (2009) and Debbagh and Jones (2018) in the United States, Loveless (2007) in the United Kingdom, Doukakis, Koilias, Adamopoulos, and Giannopoulou (2011) in Greece, Al Harbi (2014) in Saudi Arabia, Owusu, Lindsey, and Chris (2015) in New Zealand, Koh, Woo, and Lim (2013) in Singapore, to name a few.

(c) 2020 by the authors; licensee Modestum Ltd., UK. This article is an open access article distributed under the terms and conditions of the Creative Commons Attribution License (http://creativecommons.org/licenses/by/4.0/). \mailizar@unsyiah.ac.id (*Correspondence) \Ihfan@math.ecnu.edu.cn 


\section{Contribution of this paper to the literature}

- The study adopted TPACK framework, therefore, it enhances the literature regarding the application of the framework to investigate secondary mathematics teachers knowledge through a questionnaire survey.

- The study is the first empirical study in Indonesia to investigate secondary teachers' knowledge of ICT and teachers' knowledge of ICT use in teaching that involved a relative large numbers of participants.

- As a developing country that has the fourth largest education system in the world, the findings of this study has implications not only for Indonesia but for other developing countries that are keen to integrate ICT in the classroom.

In mathematics education, researchers have also investigated mathematics teachers' knowledge about ICT and the integration of ICT in mathematics classrooms, such as that by Handal, Campbell, Cavanagh, Petocz, and Kelly (2013) in Australia, Stoilescu (2015) in Canada, and Agyei and Voogt (2011) in Ghana. Those studies found that mathematics teachers did not have sufficient knowledge about ICT and how to use ICT in teaching.

However, the previous studies have left several gaps to be filled. First, regarding studies on mathematics teachers' knowledge of ICT and teachers' knowledge of ICT use in teaching, most of the studies have been conducted in developed countries. In contrast, it appears clear that there have been a limited number of publications reporting on this issue for developing countries, including Indonesia. Second, in the Indonesian context, the previous studies on teachers' knowledge about the use of ICT in teaching (e.g., Marzal, 2013; Puspiratini, Sunaryo, \& Suryani, 2013; Rimilda, 2015) also had left several gaps. For instance, Marzal's (2013) study did not investigate teachers' knowledge of using mathematical software (e.g., Dynamic Geometry and Computer Algebra System) while Rimilda's (2015) study involved five participants who were student teachers at the schools they were doing teaching practicum. As a result, those studies were not aimed to, nor did they fully reveal Indonesian secondary mathematics teachers' knowledge of ICT integration. Therefore, this study seeks to investigate Indonesian secondary mathematics teachers' knowledge of ICT and the use of ICT in mathematics teaching.

\section{AIMS AND RESEARCH QUESTION}

The aim of this study was to investigate Indonesian secondary mathematics teachers' knowledge about ICT and the use of ICT. Specifically, the study seeks to answer the following research questions: What knowledge do Indonesian secondary mathematics teachers have about ICT and its use in teaching? This study addressed teachers' knowledge into two domains: knowledge of ICT and knowledge of ICT use in teaching. Details of both concepts are explained conceptual framework section below.

\section{CONCEPTUAL FRAMEWORK}

The literature presents several frameworks that have been used to understand and investigate teachers' knowledge. A prominent one was initially proposed by Shulman (1986) and called Pedagogical Content Knowledge (PCK). This framework identifies "the distinctive bodies of knowledge for teaching" (Shulman, 1986, p. 8). He defined pedagogical content knowledge that "represents blending of content and pedagogy in an understanding of how particular topics, problems, or issues are organized, represented, and adapted to the diverse interests and abilities of learners, and presented for instruction."

Researchers (e.g., Angeli \& Valanides, 2009; Brantley-Dias, Kinuthia, Shoffner, de-Casto, \& Rigole, 2007; Chinnappan \& Thomas, 2008; Mishra \& Koehler, 2006; Niess, 2005; Pierson, 2001) extended Shulman's framework to gain insights to understand and define teachers' knowledge about the use of digital technologies. They argue that teachers need knowledge that build on and intersect with what Shulman (1986) described to use the digital tool effectively in the classroom. Therefore, this additional knowledge has been conceptualised in various ways including Technological Pedagogical Content Knowledge (TPCK) (Mishra \& Koehler, 2006; Niess, 2005; Pierson, 2001), and ICT-TPCK (Angeli \& Valanides, 2009).

Pierson (2001) believes that teachers would be able to effectively use technology in the classroom when they employ pedagogical knowledge and content knowledge extensively in combination with technology knowledge. The combination of the three knowledge areas, namely technological, pedagogical and content knowledge, would define effective technology integration. Following Pierson (2001), Niess (2005) refers to the term TPCK as technologyenhanced PCK.

Furthermore, in the same year as Niess (2005), based on their study on collaborative design of online courses by teacher educators and master students, Koehler and Mishra (2005) conceptualised the knowledge that a teacher would need to effectively teach with technology. They extended Pedagogical Content Knowledge (PCK) (Shulman, 1986) as a conceptual basis for conceptualisation of Technological Pedagogical Content Knowledge (TPCK), which was 


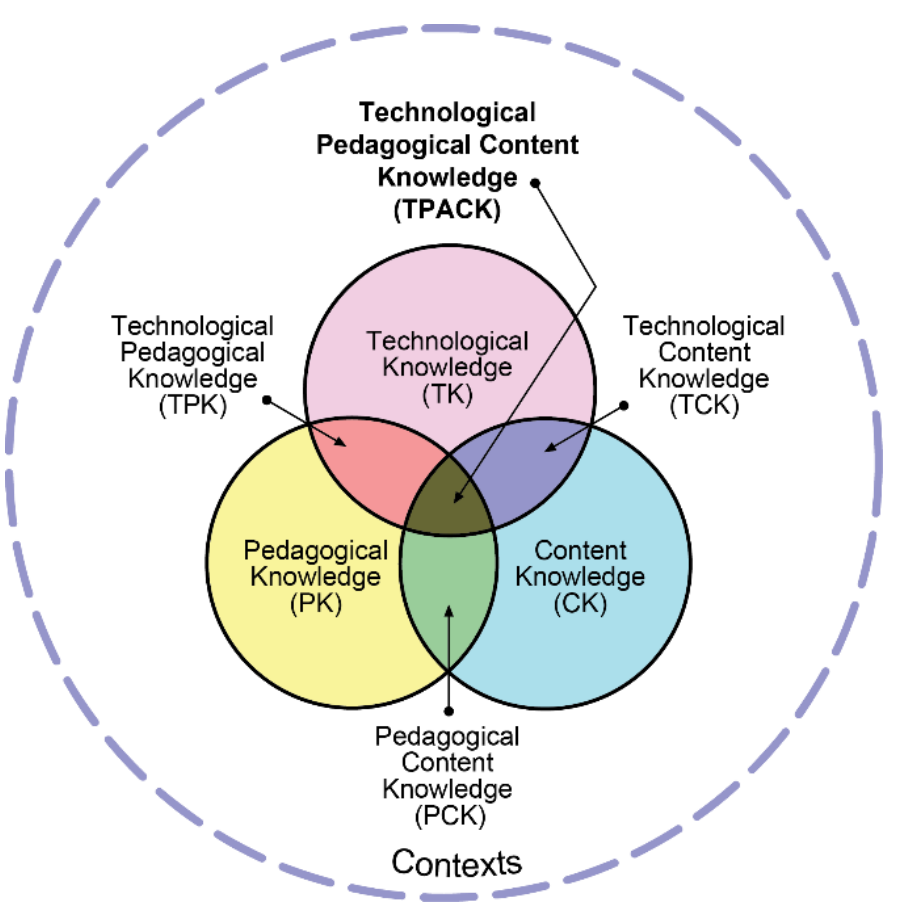

Figure 1. The components of the TPACK framework (Mishra \& Koehler, 2006)

Table 1. Definition of TPACK constructs

\begin{tabular}{ll}
\hline TPACK Constructs & Definition \\
\hline Technology knowledge (TK) & Knowledge about how to use ICT hardware and software and associated peripherals \\
\hline Content knowledge (CK) & Knowledge of the subject matter \\
\hline Pedagogical knowledge (PK) & $\begin{array}{l}\text { knowledge about the methods and processes of teaching such as classroom } \\
\text { management, assessment, lesson plan development }\end{array}$ \\
\hline Pedagogical content knowledge (PCK) & $\begin{array}{l}\text { Knowledge of representing content knowledge and adopting pedagogical } \\
\text { strategies to make the specific content/topic more understandable for the learners } \\
\text { (see Shulman, 1986) }\end{array}$ \\
\hline Technological content knowledge (TCK) & $\begin{array}{l}\text { Knowledge about how to use technology to represent and create the content in } \\
\text { different ways without consideration about teaching }\end{array}$ \\
\hline $\begin{array}{l}\text { Technological pedagogical knowledge } \\
\text { (TPK) }\end{array}$ & $\begin{array}{l}\text { Knowledge of the existence and specifications of various technologies to enable } \\
\text { teaching approaches without reference towards subject matter }\end{array}$ \\
\hline Technological pedagogical content & $\begin{array}{l}\text { Knowledge of using various technologies to teach and/represent and/ facilitate } \\
\text { knowledge creation of specific subject content }\end{array}$ \\
knowledge (TPCK) &
\end{tabular}

then abbreviated as TPACK by Thompson and Mishra (2008). According to Voogt, Fisser, Pareja Roblin, Tondeur, and van Braak (2013), the TPACK framework (see Figure 1) proposed by Mishra and Koehler (2006) has become well known compared to the other conceptualisations such as Pierson's (2001) and Niess's (2005). The core idea of the TPACK framework is the interactions between three types of knowledge: (a) technological knowledge; (b) pedagogical knowledge; and (c) content knowledge.

Chai, Koh, and Tsai (2013) define each construct of TPACK as presented in Table 1. These definitions of TPACK components seem concise and distinctive for the elements particularly in relation to TCK, TPK and TPCK.

Angeli and Valanides (2009) adapted TPACK becoming ICT-TPCK through an interaction of five areas. They renamed the technology domain as Information and Communication Technologies (ICT) as well as they added two knowledge domains: knowledge of student and knowledge of the context within which learning occurs. Therefore, in the model (see Figure 2), Angeli and Valanides (2009) present five domains of knowledge that teachers would need when they integrate ICT in teaching: content knowledge; pedagogical knowledge; knowledge of learners; knowledge of context; and knowledge of ICT.

The two models share some common principle elements. First, they strongly address the existing various components of digital technology and their affordance for teaching and learning. This requires teachers to understand ICT broadly enough to apply it effectively in the classroom and to recognise when ICT can assist them in achieving the goal of teaching and learning. Second, the integration of ICT in teaching requires teachers to understand the existence of various ICT tools and their pedagogical affordance (see Angeli \& Valanides, 2009; 


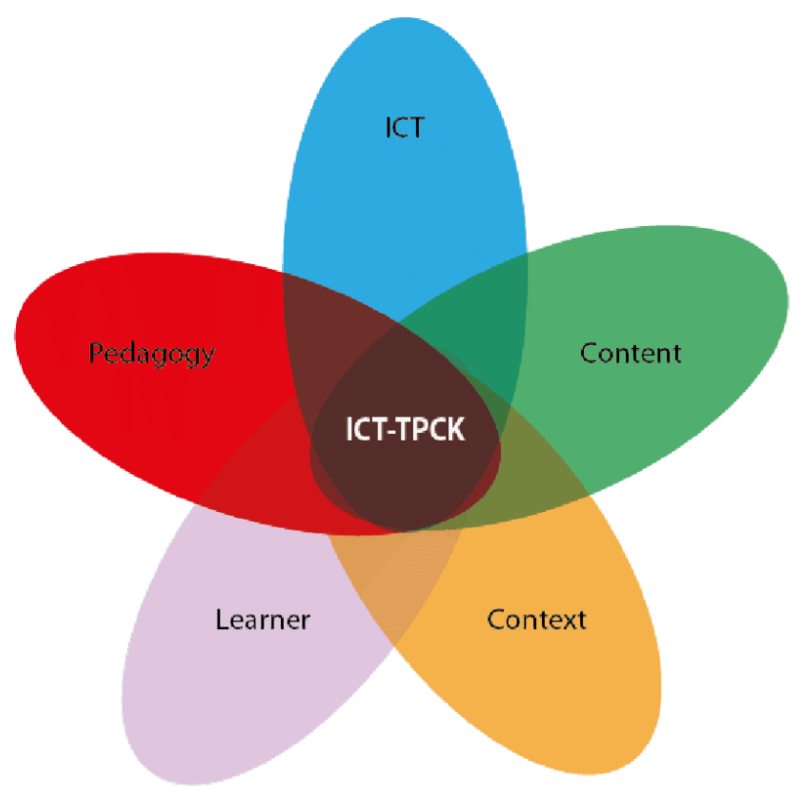

Figure 2. ICT-TPCK (Angeli \& Valanides, 2009)

Mishra \& Koehler, 2006). Finally, both models also address knowledge of pedagogical strategies and ability to apply those strategies for the use of ICT for a specific learning tasks or contents. Drawing upon those two models, we classified constructs of knowledge investigated in this study as follows.

We adopted Angeli and Valanides's (2009, p. 158) definition to define knowledge of ICT that is knowing how to operate a computer and how to use a multitude tools/software as well as troubleshoot in problematic situation. This is similar to Chai et al. (2013) definition which is knowledge about how to use hardware and software and associated peripherals. The definition of knowledge of ICT in this study is knowing how to operate hardware as well as knowing how to use software and the internet.

Knowledge of ICT use in teaching is a complex notion, and it is a challenge to develop a concise definition of this concept. We defined it based on TPCK (Mishra \& Koehler, 2006) that has seven components namely TK, CK, PK, PCK, TCK, TPK, TPCK. Handal et al. (2013) adopted the TPCK model to investigate secondary mathematics teachers' knowledge through administration of an instrument called TPCK-M (Technological Pedagogical Content Knowledge of Mathematics) $\mathrm{n}$ consisted of three major theoretically-based constructs: technological content knowledge (TCK), technology pedagogical knowledge (TPK), and technological pedagogical content knowledge (TPCK). The instrument of teachers' knowledge of ICT use in teaching consisted of TCK, TPK and TPCK, which we then reframed as: ICT-Content Knowledge (ICT-CK), ICT-Pedagogical Knowledge (ICT-PK) and ICT-Pedagogical Content Knowledge (ICT-PCK).

Finally, based the discussion above, the construct of teachers' knowledge investigated in this study is presented in Table 1.

\section{METHOD}

\section{Research Design}

The study adopted a quantitative approach, as it is considered to provide more reliability, validity, objectivity and generalizability to the findings. More specially, a questionnaire can be administered to a large number of participants. As it has been argued, if the researchers collects data based on a representative sample of the population, by employing a quantitative approach, they are more able to generalise statements made about the topic being examined (Fraenkel \& Wallen, 2009).

\section{Research Participants}

Indonesia is a large country, and due to practical reasons we were unable to collect data throughout the whole country. The population for this study was, in a strict sense, all the upper secondary mathematics teachers who teach grade 10-12 students in one of Indonesia's provinces, which has 367 senior secondary schools and 1,443 
Table 2. Construct of knowledge of ICT and knowledge of ICT use in teaching

\begin{tabular}{ll}
\hline Construct of Knowledge & Description \\
\hline Knowledge of ICT & $\begin{array}{l}\text { Knowing how to operate hardware and how to use software and the internet without } \\
\text { consideration of any mathematical content and teaching approaches }\end{array}$ \\
\hline Knowledge of ICT use in teaching & Description \\
\hline ICT-Content Knowledge & $\begin{array}{l}\text { Knowing how to use ICT to represent, communicate, solve and explore mathematical } \\
\text { contents, ideas, or problems without consideration of teaching approaches. }\end{array}$ \\
\hline ICT-Pedagogical Knowledge & $\begin{array}{l}\text { Knowing how to use ICT to provide advantages to specific aspects of teaching } \\
\text { approaches without reference to specific subject matter }\end{array}$ \\
\hline ICT-Pedagogical Content Knowledge & $\begin{array}{l}\text { Knowing how to use ICT to teach, represent and facilitate learning of specific content } \\
\text { of mathematics with specific teaching approaches to enhance teaching and learning }\end{array}$ \\
\hline
\end{tabular}

mathematics teachers. To determine the sample size, we referred to the table for determining minimum returned sample size developed by Barlett, Kotrlik, and Higgins (2001). According to the table, with a confidence interval (margin of error) of $+/-5 \%$, and a confidence level of $95 \%$, about 306 participants were required for the sample. We randomly selected schools from each city and regency in the province. In total, there were 93 secondary schools selected for the distribution of 440 copies of the questionnaires. In total, 355 questionnaires were returned. However, 14 questionnaires were found incomplete. Participants' demographic backgrounds are presented in Table 2.

\section{Research Instrument}

We developed a questionnaire that included two parts, namely, teacher' demographic backgrounds and teachers' knowledge. With regard to teachers' knowledge of ICT, as previously discussed in the conceptual framework section, this study refers to the definition proposed by Angeli and Valanides (2009, p. 158). In terms of teachers' knowledge of ICT use in teaching, as previously discussed, this study refers to Mishra \& Koehler's TPACK (2006) and Handal et al. (2013). Some questionnaire items about teachers' knowledge of ICT use into teaching were adopted from Handal et al. (2013). This is because, as mentioned earlier, they also adopted the TPACK model to develop a questionnaire called TPCK-M that consists of three constructs: technological content knowledge (TCK), technology pedagogical knowledge (TPK), and technological pedagogical content knowledge (TPCK). Furthermore, all the responses on teachers' knowledge were coded in a 5-point scale, ranging from $1=$ strongly disagree to 5 = strongly agree (See. Appendix).

\section{Reliability and Validity}

Reliability. Internal consistency reliability was employed to examine the instrument's reliability. The inter-item correlation was assessed by using Cronbach's coefficient alpha of over 0.7 (Muijs, 2004). The result showed that data the instrument has reasonably high reliability with an alpha coefficient of .974 .

Validity. Content and construct validity were used to evaluate the validity of the questionnaire. Regarding content validity, as mentioned previously, the development of the questionnaire was based on the literature review and conceptual framework as well as the existing instruments. Moreover, the process of development took several stages involving experts reviewing the instrument aiming to enhance content validity of the instrument. Confirmatory factor analysis was use to examine whether each item measures the subscale that was supposed to measure. According to Muijs (2004), factor loading for survey items helps to show a correction between the item and the overall factor. The results showed that a value of scales of teachers' knowledge is .944 , which falls into the range of being superb. Moreover, all items were grouped into one of the four factors. Factor analysis of the data revealed four factors (eigenvalues of 17.3, 2.9, 2.1 and 1.0) and 75.5\% of total variation was explained by these factors. This scale had high factor loading (ranging from .634 to $.822, .756$ to $.816, .614$ to .874 , and .556 to .645 on these fours factors).

\section{Data Analysis Procedure}

All responses on teachers' knowledge were coded in a 5-point scale. Descriptive and inferential statistical analysis were employed to answer the research questions. Regarding descriptive analysis, a frequency distribution of responses on all the items of teachers' knowledge was calculated and presented in tables. Furthermore, Means of all the items were also explained by using Handal et al.'s (2013) questionnaire score range (See Table 3). For inferential statistical analysis, a repeated measure ANOVA and paired- $t$ test were employed to examine significant differences in teachers' knowledge across survey items. 
Table 3. Participants Demographic Background

\begin{tabular}{lcc}
\hline Demographic Background & Frequency & Percentage \\
\hline Gender & 213 & 62.6 \\
\hline Male & 128 & 37.4 \\
\hline Female & & 5 \\
\hline 30 Years or Less & 17 & 20.8 \\
\hline $31-35$ Years & 71 & 27.5 \\
\hline $36-45$ Years & 94 & 29.4 \\
\hline $46-55$ Years & 100 & 17.3 \\
\hline Over 55 Years & 59 & \\
\hline Teaching Experience & & 16.9 \\
\hline Over 30 years & 58 & 27.2 \\
\hline $21-30$ Years & 93 & 21.9 \\
\hline $11-20$ Years & 76 & 24.6 \\
\hline $6-10$ Years & 82 & 9.5 \\
\hline 1-5 Years & 32 & 8.6 \\
\hline Highest Level of Education & 29 & 90.8 \\
\hline Post Graduate Degree & 310 & 0.6 \\
\hline Undergraduate Degree & 2 & \\
\hline Post-Secondary Degree & & \\
\hline
\end{tabular}

Table 4. Questionnaire score range

\begin{tabular}{cc}
\hline Score Range & Score Range \\
\hline $1.0 \leq x<1.5$ & Very low \\
\hline $1.5 \leq x<2.0$ & Low \\
\hline $2.0 \leq x<2.5$ & Moderately low \\
\hline $2.5 \leq x<3.0$ & Slightly below average \\
\hline 3.0 & Average \\
\hline $3.0<x \leq 3.5$ & Slightly above average \\
\hline $3.5<x \leq 4.0$ & Moderately high \\
\hline $4.0<x \leq 4.5$ & High \\
\hline $4.5<x \leq 5.0$ & Very high \\
\hline
\end{tabular}

\section{RESULTS}

As previously discussed, the study investigated secondary mathematics teachers' knowledge and of ICT and teachers' knowledge of ICT in teaching. We present results of both types of knowledge from the survey. We first present mean scores and standard deviations for each items, which is then followed by results of repeated measure ANOVA and a paired-t test.

\section{Teachers' Knowledge of ICT}

We present the results of the teachers' knowledge of ICT in Table 4, including knowledge of hardware, knowledge of general software, knowledge of mathematical software and knowledge of online resources. The mean score of knowledge of hardware was 3.14 which indicates slightly above average, and their knowledge of computer/laptop was higher than their knowledge of calculator and tablet/handheld device.

Moreover, the mean score of teachers' knowledge of general software was 2.71, indicating that the participants' knowledge of this was slightly below average. It also showed that the participants' knowledge of word processing software was higher than their knowledge of the other general software. The results revealed that teachers' knowledge of mathematical software was moderately low (Mean $=2.07$ ). For this type of software, the results showed that participants' knowledge of Dynamic Mathematics Software and Dynamic Geometry Software were higher than their knowledge of Computer Algebra System and Statistical Software. In addition, the results revealed that participant's knowledge of online resources was moderately low (Mean $=2.14$ ) in which their knowledge of online teaching and learning resources was higher than their knowledge of learning management system software. As most mean scores fall into the low category, it can be concluded that teachers had insufficient knowledge of ICT.

A repeated measures ANOVA was run in order to determine if there was statistically significant difference in teachers' knowledge of hardware, teachers' knowledge of general software, and teachers' knowledge of 
Table 5. Mean scores of participants' responses to items of ICT knowledge

\begin{tabular}{|c|c|c|}
\hline Teachers' Knowledge of ICT & Mean & Standard Deviation \\
\hline \multicolumn{3}{|l|}{ Knowledge of hardware } \\
\hline a. Graphing Calculator & 2.57 & 1.22 \\
\hline b. Tablet/Mobile Device & 3.18 & 1.04 \\
\hline c. $\quad$ Computer/Laptop & 3.66 & 0.88 \\
\hline Mean & 3.14 & \\
\hline \multicolumn{3}{|l|}{ Knowledge of general software } \\
\hline a. $\quad$ Word processor software(e.g., Ms Word) & 3.85 & 0.90 \\
\hline b. Presentation software (e.g., Ms PowerPoint) & 3.54 & 0.98 \\
\hline c. $\quad$ Online presentation software (e.g., Prezi) & 1.99 & 0.94 \\
\hline d. $\quad$ Spreadsheet software (e.g., Ms Excel) & 3.48 & 1.01 \\
\hline e. $\quad$ Mind mapping software (e.g., Inspiration) & 2.04 & 0.99 \\
\hline f. $\quad$ Animation software (e.g., Macromedia Flash) & 2.17 & 1.00 \\
\hline g. Three dimensional visualisation software (e.g., Sketch Up) & 1.91 & 0.92 \\
\hline Mean & 2.71 & \\
\hline \multicolumn{3}{|l|}{ Knowledge of Mathematical software } \\
\hline a. $\quad$ Computer Algebra System (e.g., Maple and Maxima) & 2.09 & 1.10 \\
\hline b. Dynamic Geometric Software (e.g., Geometer's Sketchpad and Cabri Geometry) & 2.04 & 1.01 \\
\hline c. Dynamic Mathematics Software (e.g., Geogebra and Autograph) & 2.32 & 1.06 \\
\hline d. Statistical Software (e.g., Tinkerplots and Fathom) & 1.87 & 0.92 \\
\hline Mean & 2.07 & \\
\hline \multicolumn{3}{|l|}{ Knowledge of online tools } \\
\hline a. $\quad$ Online Learning Resources (e.g., Khan Academy) & 2.21 & 1.18 \\
\hline b. $\quad$ Learning Management System (e.g., Moodle) & 2.07 & 1.06 \\
\hline Mean & 2.14 & \\
\hline
\end{tabular}

mathematical software across the items. In terms of teachers' knowledge of hardware, Mauchly's test indicated that the assumption of sphericity had been violated, $x^{2}(2)=28.07, \mathrm{p}=0.00$, therefore the degree of freedom was corrected using Huynh-Feldt estimate of sphericity $(\varepsilon=.92)$. The results show that there was significant difference in teachers' level of knowledge of hardware across the items, i.e., from high to low, knowledge about computer/laptop, tablet/mobile device, and graphing calculators $(\mathrm{F}(1.84,540.01)=163.21, \mathrm{p}=0.00)$.

Regarding teachers' knowledge of general software, Mauchly's test indicated that the assumption of sphericity had been violated, $x^{2}(20)=516.59, \mathrm{p}=0.00$, therefore the degree of freedom was corrected using the GreenhouseGeisser estimate of sphericity $(\varepsilon=.48)$. The results show that there was a significant difference in teachers' level of knowledge of general software across the items, from the highest about word processor software (e.g., MS Word), presentation software (e.g., MS PowerPoint) and spreadsheet software (e.g., MS Excel) to the lowest about three dimensional visualisation software (e.g., Sketch Up), online presentation software (e.g., Prezi) and mind mapping software (e.g., Inspiration) $(\mathrm{F}(2.86,686.55)=461.36, \mathrm{p}=.00)$.

In terms of teachers' knowledge of mathematical software, Mauchly's test indicated that the assumption of sphericity had been violated, $x^{2}(44)=615.47, p=0.00$, therefore the degree of freedom was corrected using the Greenhouse-Geisser estimate of sphericity $(\varepsilon=.69)$. The results showed that there was a significant difference in teachers' level of knowledge of mathematical software across the items, from the highest to the lowest, about Dynamic Mathematics Software (e.g., Geogebra and Autograph), about Computer Algebra System (e.g., Maple and Maxima), about Dynamic Geometric Software (e.g., Geometer's Sketchpad and Cabri Geometry), and about Statistical Software (e.g., Tinkerplots and Fathom) $(F(6.38,1665.11)=35.48, \mathrm{p}=0.00)$.

Moreover, a paired t-test was carried out to examine if there was a statistically significant difference in teachers' knowledge of online resources across the two items. The results showed that there was a significant difference in the score for teachers' knowledge for online learning resources $(\mathrm{M}=2.21, \mathrm{SD}=1.18)$ and learning management systems $(\mathrm{M} 2.07, \mathrm{SD}=1.06) ; \mathrm{t}(287)=4.15, \mathrm{p}=.00$, implying that, according to the responses, the teachers' knowledge regarding online learning resources is significantly better than their knowledge about learning management system.

\section{Teachers' Knowledge of ICT Use in Teaching}

As aforementioned, in this study, teachers' knowledge of ICT use in teaching consisted of three components, namely ICT-content knowledge, ICT-pedagogical knowledge and ICT-pedagogical content knowledge. Table 5 depicts the participating teachers' responses to all the related questionnaire items in the survey in terms of the mean scores. 
Table 6. Mean scores of participants' responses to items of ICT-content knowledge

\begin{tabular}{|c|c|c|}
\hline Teacher Knowledge of ICT Use in Teaching & Mean & Std. Deviation \\
\hline \multicolumn{3}{|l|}{ ICT-Content Knowledge } \\
\hline a. Use ICT to represent mathematical ideas & 3.10 & 1.03 \\
\hline Use ICT to communicate mathematical processes & 3.02 & 1.08 \\
\hline Use ICT to solve mathematical problems & 2.90 & 1.10 \\
\hline d. Use ICT to explore mathematical ideas & 2.84 & 1.08 \\
\hline Mean & 2.96 & \\
\hline \multicolumn{3}{|l|}{ ICT-Pedagogical Knowledge } \\
\hline a. Use ICT for direct instruction & 3.33 & 0.93 \\
\hline b. Use ICT for inquiry-based teaching and learning & 3.14 & 0.94 \\
\hline Use ICT for project-based teaching and learning & 2.85 & 0.95 \\
\hline d. Use ICT for discovery-based teaching and learning & 2.81 & 0.91 \\
\hline $\begin{array}{l}\text { e. Use ICT for collaborative-based teaching and learning } \\
\end{array}$ & 2.72 & 0.97 \\
\hline Mean & 2.97 & \\
\hline \multicolumn{3}{|l|}{ ICT-Pedagogical Content Knowledge } \\
\hline $\begin{array}{l}\text { a. Use ICT to teach topics of mathematics that are better learned when employing specific teaching } \\
\text { approaches }\end{array}$ & 3.20 & 0.90 \\
\hline $\begin{array}{l}\text { b. Use strategies that combine mathematical content, ICT and teaching approaches to support } \\
\text { students' understandings as they are learning mathematics }\end{array}$ & 3.10 & 0.93 \\
\hline Use ICT in teaching that enhances mathematical content and how it taught & 3.06 & 0.97 \\
\hline d. Use ICT to incorporate authentic tasks in teaching mathematics through project-based learning & 2.88 & 1.08 \\
\hline $\begin{array}{l}\text { e. Use ICT to teach students to develop their mathematics problem solving through inquiry-based } \\
\text { learning }\end{array}$ & 2.07 & 1.06 \\
\hline Mean & 2.87 & \\
\hline
\end{tabular}

The results show that teachers' ICT-content knowledge $($ Mean $=2.96)$, ICT-pedagogical knowledge $($ Mean $=$ 2.97 ) and ICT-pedagogical content knowledge (Mean $=2.87$ ) were slightly below average. The results suggest that teachers had insufficient knowledge of ICT use in teaching.

In order to determine if there was a statistically significant difference in teachers' knowledge across the categories, we run repeated measures ANOVA. Mauchly's test indicated that the assumption of sphericity had been violated, $x^{2}(2)=97.98, p=0.00$, therefore the degree of freedom was corrected using Huynh-Feldt estimate of sphericity $(\varepsilon=.80)$. The results showed that there was significant differences in teachers' level of knowledge of ICT use in teaching across those three components, i.e., from high to low, about ICT-pedagogical knowledge, about ICT-content knowledge and about ICT-pedagogical content knowledge $(F(1.59,513.85)=48.9, \mathrm{p}=.013)$. The results suggest that teachers' ICT-pedagogical content knowledge was the lowest one across all categories of teachers' knowledge of ICT use in teaching.

\section{DISCUSSION}

The study of teachers' knowledge of the use of ICT in teaching has gained more attention in this decade. Such study continues to be relevant for understanding and improving the integration of digital technology in the classroom. As this study focused on teachers' knowledge of ICT and teachers' knowledge of ICT use into teaching, we discuss and relate the finding to the literature regarding both types of knowledge.

To a large extent, the findings revealed that Indonesian secondary mathematics teachers had insufficient knowledge of ICT and ICT use in teaching. Regarding the knowledge of hardware, the findings revealed that the participants' knowledge of computers/laptops was higher than their knowledge of tablets/handheld devices, which is higher than their knowledge about graphing calculators. It is not surprising that teachers perceived their knowledge of computers/laptops to be high due to the fact they need to use this tool in daily life. However, that the lowest level of teachers' knowledge was found in the area of graphing calculator, is quite surprising to us. According to the literature (see Mailizar, Manahel, \& Fan, 2014; Ruseffendi, 1988), the integration of calculators in Indonesian secondary mathematics classrooms has been attempted since 1984. It seems that a long history of the use of this digital tool in policy directives does not have a significant impact on teachers' knowledge of this tool. Furthermore, according to Mailizar (2018), only $25.5 \%$ of the mathematics teaches had learned how to use the graphic calculator.

Along with knowledge of operating hardware, we also looked at teachers' knowledge of general hardware and mathematical software. The results showed that the participants' knowledge of general software was higher than their knowledge of mathematical software. This finding supports Fuglestad's (2007) study which revealed that teachers had some basic knowledge of software for general use such as word processing and the spreadsheets but 
the teachers had lack of knowledge of specific mathematics software such as dynamic geometry software. This finding indicates that, with widely available specific software for teaching and learning mathematics, Indonesian secondary mathematics teachers need to enhance knowledge of mathematical software as it is widely believe such knowledge plays significant role in designing and implementing ICT-based mathematics lessons in the classroom.

The majority of participants reported that their knowledge of word processor software (e.g., MS Word) was the highest one which then followed by their knowledge of presentation software (e.g., MS PowerPoint). The finding is not surprising since such software are widely available and commonly used on many occasions. It is in line with Kazoka and William's (2016) study in Tanzania revealing that the majority (75\%) of secondary school teachers were able to use MS Word and $50 \%$ of teachers were able to use MS PowerPoint. In the Indonesian context, this finding supports Marzal's (2013) study showing that over $60 \%$ of science and mathematics teachers have knowledge of using MS PowerPoint, MS Word, and the Internet while less than $10 \%$ of the teachers are able to use specific software such as SPSS. However, teachers' knowledge of general software might not has significant impact on the integration of ICT in mathematics classrooms since such software do not have features for facilitating students to construct their mathematical knowledge.

When it comes teachers' knowledge of mathematical software, the findings revealed that teachers' knowledge of this category of software was lower than their knowledge of general software. As mentioned earlier, in this study, we investigated teachers' knowledge of several types of mathematical software: Dynamic Mathematics Software (DMS), Dynamic Geometry Software (DGS), Computer Algebra System (CAS), and Statistical Software. The results revealed that teachers' knowledge of DMS and DGS to be higher than their knowledge about Statistical Software and CAS. Jones (2005) also found the similar finding and suggested that it is reasonable for teachers to rate their knowledge of DGS higher than their knowledge of other types of software since DGS has become the most widely used software in schools all over the world. To gain a better understanding on teachers' knowledge of DMS and DGS, we looked specific software and found that teacher knowledge of GeoGebra was the highest one across DMS and DGS software. As open source software, GoeGebra is widely available and easily accessible for students and teachers. This condition might have had an impact on teachers' knowledge of this software. We believe that it is potential to improve Indonesian mathematics teachers' knowledge of mathematical software, as it has been emerged over small numbers of teachers.

The last aspect of teachers' ICT knowledge is knowledge of online resources. The results show that teachers' had low knowledge of these resources in which their knowledge of learning management systems (LMS) was lower than knowledge of online learning resources. According to Pynoo et al. (2012) LMS is relatively new technology in secondary education as this technology was first adopted in higher education. As a new technology, it is not surprising that the teachers do not have the sufficient knowledge to use it.

As described earlier, the second aspect of teachers' knowledge investigated in this study was teachers' knowledge of ICT use in teaching. The finding revealed teachers do not have sufficient knowledge of ICT use in teaching. As discussed in the conceptual framework, this study adapted the TPACK framework in investigating this knowledge. Hence, the findings are discussed and related to previous studies using the framework.

The finding is consistent with previous studies using the TPACK framework to understand teachers' knowledge in other countries such as (e.g., Al Harbi, 2014; Archambault \& Crippen, 2009). For instance, Al Harbi found that Saudi high school teachers (not limited to mathematics teachers) have a low to moderate level of TPACK knowledge.

Concerning mathematics teachers, the similar finding was also found by Agyei and Voogt (2011) and Handal et al. (2013). This indicates mathematics teachers' lack of knowledge about integrating ICT has been an issue not only in developing countries such as Ghana (see Agyei \& Voogt, 2011) but also in developed countries such as Australia (see Handal et al., 2013). Consequently, it becomes a challenge for education stockholders in countries across the globe, including Indonesia, to improve teachers' knowledge of this aspect in order to support the integration of the technology.

As discussed in the conceptual framework section, teachers' knowledge in the use of ICT consists of three aspects: ICT-Content Knowledge, ICT-Pedagogical Knowledge, and ICT-Pedagogical Content Knowledge. The results revealed that teachers' ICT-Content Knowledge and ICT-Pedagogical Knowledge were higher than teachers' ICT-Pedagogical Content Knowledge which is in line with Al Harbi's (2014) study. This indicates that ICT-Pedagogical Content Knowledge is more sophisticated and complex than ICT-Pedagogical Knowledge and ICT-Content Knowledge. Consequently, teachers find it much more difficult to gain this knowledge.

It appears clear from this study that Indonesian secondary mathematics teachers' lack of knowledge of both ICT and ICT use might link to the deficiency of training programs as it was found by Mailizar (2018) that revealed that $35 \%$ of Indonesian secondary mathematics teachers had never participated in any ICT-related training course. Furthermore, a large number (46\%) of Indonesian secondary mathematics teachers are aged over 46 years old and they are described by Harendita (2013) as digital migrants. Digital migrants are widely believed to be less quick to 
adopt new technologies than digital native and they need more professional development and training concerning ICT and its use in classroom.

Finally, this study suggests that it is crucial to equip Indonesian secondary mathematics teachers with knowledge of ICT and knowledge of ICT use in teaching through providing training courses emphasising on connection of pedagogical and mathematical content of ICT integration rather than simply training on technical knowledge for the use of ICT resources. This has been strongly supported by research evidence in the literature (e.g., Becta, 2004; Hew \& Brush, 2007; Koehler \& Mishra, 2005). For example, Koehler and Mishra (2005) argue that, when training teachers to integrate ICT in teaching, it is important to teach ICT in contexts that represent the connection between technology, content and pedagogy.

\section{CONCLUSION}

This study investigated Indonesia secondary mathematics teachers' knowledge of ICT and teachers' knowledge of ICT use in teaching. The results of this study revealed that, to large extent, Indonesian secondary mathematics teachers had insufficient knowledge of ICT and knowledge of ICT use in teaching. It revealed that teachers' knowledge of computer was higher than their knowledge of handheld devices and graphing calculator. The finding also suggested that teachers' knowledge of general software was higher than their knowledge of mathematical software. Regarding knowledge of ICT use in teaching, this study depicted that teachers' ICT-Pedagogical Content Knowledge was lower than teachers' ICT-Pedagogical Knowledge and ICT-Content Knowledge.

Based on the findings, we suggest several important points that need to take into account. For future research, it needs a further study to examine the development of Indonesian secondary school's mathematics teacher's knowledge in the use of ICT for teaching a specific content of mathematics, such as Geometry and Algebra. Furthermore, regarding practical implication, the study suggests that Indonesian education stakeholders need to facilitate secondary mathematics teachers in improving their knowledge of ICT and knowledge of ICT use in teaching. Particularly, the Indonesian government needs to provide ICT training courses to improve not only teachers' technical knowledge of the use of ICT and their pedagogical and mathematical content knowledge of ICT integration.

\section{ACKNOWLEDGEMENTS}

The completion of this paper was in part supported financially by a research grant from the Asian Centre for Mathematics Education, East China Normal University (Project No. 92900-120215-10514).

\section{REFERENCES}

Agyei, D. D., \& Voogt, J. (2011). ICT use in the teaching of mathematics: Implications for profesional development of pre-service teacher in Ghana. Educational Information Technology, 16, 423-439. https:/ / doi.org/10.1007/s10639-010-9141-9

Al Harbi, H. E. M. (2014). An examination of Saudi high school teachers' ICT knowledge and implementation. Queensland University of Technology, Queensland.

Angeli, C., \& Valanides, N. (2009). Epistemological and methodological issue for the conceptualization, development, and assessment of ICT-TPCK: Advance in technilogical pedagogical content knolwedge (TPCK). Computer E Education, 52, 154-168. https:/ / doi.org/10.1016/j.compedu.2008.07.006

Archambault, L., \& Crippen, K. (2009). Examining TPACK among K-12 online distance educators in the United States Contemporary Issues in Technology and Teacher Education, 9(1), 71-88.

Barlett, J. E., Kotrlik, J. W., \& Higgins, C. C. (2001). Organizational research: Determining appropriate sample size in survey research. Information technology, learning, and performance journal, 19(1), 43.

Becta. (2004). A review of the research literature on barriers to the uptake of ICT by teachers. Conventry: British Educational Communication and Technology Agency.

Brantley-Dias, L., Kinuthia, W., Shoffner, M., B, de-Casto, C., \& Rigole, N., J. (2007). Developing Pedagogical Technology Integration Content Knowledge in preservice teachers: A case study approach. Journal of Computing in Teacher Education, 23(4), 143-149.

Chai, C., Koh, J. H. L., \& Tsai, C. C. (2013). A Review of Technological Pedagogical Content Knowledge. Educational Technology \& Society, 16(2), 31-51.

Chinnappan, M., \& Thomas, M. (2008). Teaching and learning with technology: Realising the potential. In H. J. Forgasz, A. Barkatsas, B. Bishop, S. Clarke, W. Keast, Seah \& P. Sullivan (Eds.), Research in mathematics education in Australasia 2004-2007. 
Clark-Wilson, A., Robutti, O., \& Siclair, N. (Eds.). (2014). The mathematics teacher in the digital era: Mathematics education in the digital era (Vol. 2). New York: Springer. https:/ / doi.org/10.1007/978-94-007-4638-1

Debbagh, M., \& Jones, W. M. (2018). Examining English language teachers' TPACK in oral communication skills teaching. Journal of Educational Multimedia and Hypermedia, 27(1), 43-62.

Doukakis, S., Koilias, C., Adamopoulos, N., \& Giannopoulou, P. (2011). Computer Science Teachers' In-service Training Needs and Their Technological Pedagogical Content Knowledge. Paper presented at the World Summit on Knowledge Society, Heidelberg, Germany.

Fraenkel, J. R., \& Wallen, N. E. (2009). How to design and evaluate research in education (Vol. 7). Boston: MacGraw-Hill.

Handal, B., Campbell, C., Cavanagh, M., Petocz, P., \& Kelly, N. (2013). Tecnologycal Pedagogical Content Knowledge of secondary mathematics teachers. Contemporary Issues in Technology and Teacher Education, 13(1), 22-40.

Harendita, M. (2013). Why Resist? A Closer Look at Indonesian Teachers' Resistance to ICT International Journal of Indonesian Studies, 1, 41-57.

Hennessy, S., Fung, P., \& Scanlon, E. (2001). The role of the graphic calculator in mediating graphing activity International Journal of Mathematics for Education in Science and Technology, 32(2), 267-290. https:/ / doi.org/10.1080/00207390010022176

Hew, K. F., \& Brush, T. (2007). Integrating technology into K-12 teaching and learning: Current knowledge gaps and recommendation for future research Educational Technology Research and Development, 55, $223-252$. https:/ / doi.org/10.1007/s11423-006-9022-5

Jones, K. (2005). Implications for the classroom: Research on the use of dynamic software. In J. Edwards \& D. Wright (Eds.), Integrating ICT into the Mathematics Classroom (pp. 27-29). Derby: Association of Teachers of Mathematics.

Kazoka, R., \& William, F. (2016). Secondary school teachers' knowledge and practice toward the use of ICT. Merit Research Journal of Education and Review, 4(2), 14-18.

Koehler, M. J., \& Mishra, P. (2005). What happens when teachers design educational technology? The development of technological pedagogical content knowledge Journal of Educational Computing Research, 32, 131-152. doi: https://doi.org/10.2190/0ew7-01wb-bkhl-qdyv

Koh, J. H. L., Woo, H.-L., \& Lim, W.-Y. (2013). Understanding the relationship between Singapore preservice teachers' ICT course experiences and technological pedagogical content knowledge (TPACK) through ICT course evaluation. Educational Assessment, Evaluation and Accountability, 25(4), 321-339. doi: https:// doi.org/10.1007/s11092-013-9165-y

Loveless, A. (2007). Preparing to teach with ICT: subject knowledge, Didaktik and improvisation. The Curriculum Journal, 18(4), 509-522. doi: https://doi.org/10.1080/09585170701687951

Mailizar, Manahel, A., \& Fan, L. (2014). A historical overview of Mathematics curriculum reform and development in modern Indonesia. Teaching Innovations, 27(3). doi: doi:10.5937/inovacije1403058M

Mailizar. (2018). Investigating Indonesian teachers' knowledge and use of ICT in mathematics teaching. (PhD), University of Southampton.

Marzal, J. (2013). Pengembangan skill dan kompetensi TIK guru Matematika dan IPA di kota Jambi melalui etutorial berbasis kebutuhan guru [Improvement of mathematis teachers' comptence and skill of ICT through teacher's need based e-tutorial]. Tehno-Pedagogy, 3(1), 28-41.

Mishra, P., \& Koehler, M. J. (2006). Technological pedagogical content knowledge: A framework for teacher knowledge. Teachers College Record, 108(6), 1017-1054. https:/ / doi.org/10.1111/j.1467-9620.2006.00684.x

Muijs, D. (2004). Doing quantitative research in education with SPSS. London: Sage. https:/ / doi.org/10.4135/9781849209014

Niess, M. L. (2005). Preparing teachers to teach science and mathematics with technology: Developing a technology pedagogical content knowledge. Teaching and Teacher Education," 21(5), 509-523. https://doi.org/10.1016/j.tate.2005.03.006

Owusu, K. A., Lindsey, C., \& Chris, A. (2015). Assessing New Zealand high school science teachers' technological pedagogical content knowledge Journal of Computers in Mathematics and Science Teaching, 34(3), 345-373.

Pierson, M. (2001). Technology integration practice as a fuction of pedagogical expertise. Journal of Research on Technology in Education, 33(4), 413-430. https:/ / doi.org/10.1080/08886504.2001.10782325

Puspiratini, E. W., Sunaryo, S., \& Suryani, E. (2013). Pemodelan Technological Pedagogical Content Knowledge (TPACK) berbasis teknologi informasi komunikasi (TIK) dengan pendekatan struktiral equation modeling (SEM) Paper presented at the Seminar Nasional Manajemen Teknologi XVIII, Surabaya, Indonesia. 
Pynoo, B., Tondeur, J., Van Braak, J., Duyck, W., Sijnave, B., \& Duyck, P. (2012). Teachers' acceptance and use of an $\begin{array}{llllll}\text { educational portal. } & \text { Computers } & \mathcal{E} & \text { Education, } & \text { 58(4), } & \text { 1308-1317. }\end{array}$ https://doi.org/10.1016/j.compedu.2011.12.026

Rimilda, R. (2015). Analysis Technological Pedagogical Content Knowledge Mahasiswa Program Studi Pendididikan Matematika FKIP Unsyiah pada materi Bangun Ruang Sisi Datar [Analysing of Unsyiah's Pre-service teachers' TPACK on Topic of three-dimensional geometry. (Master), Syiah Kuala University, Banda Aceh, Indonesia.

Ruseffendi, E. T. (1988). Pengantar kepada membantu guru mengembangkan kompetensinya dalam pengajaran matematika untuk meningkatkan CBSA [Introduction to help teachers to develop competence in teaching mathematics to improve the student active learning]. Bandung, Indonesia: Tarsito.

Shulman, L. S. (1986). Those who understand: Knowledge growth in teaching. Educational Researcher, 15(2), 4-14. https://doi.org/10.3102/0013189X015002004

Sinclair, N., \& Jackiw, N. (2005). Understanding and projecting ICT trends in mathematics education. Teaching secondary mathematics with ICT, 235-251.

Smeets, E. (2005). Does ICT contribute powerful learning environments in primary education? . Computer $\mathcal{E}$ Education, 44, 345-355. https://doi.org/10.1016/j.compedu.2004.04.003

Stoilescu, D. (2015). A critical examination of the technological pedagogical content knowledge framework: Secondary school mathematics teachers integrating technology. Journal of Educational Computing Research, 52(4), 514-547. https:// doi.org/10.1177/0735633115572285

Thompson, A., \& Mishra, P. (2008). Breaking news: TPCK becomes TPACK! . Journal of Computing in Teacher Education, 24(2), 38-64.

Voogt, J., Fisser, P., Pareja Roblin, N., Tondeur, J., \& van Braak, J. (2013). Technological pedagogical content knowledge-a review of the literature. Journal of Computer Assisted Learning, 29(2), 109-121. https:/ / doi.org/10.1111/j.1365-2729.2012.00487.x

Witte, K. D., \& Rogge, N. (2014). Does ICT matter for effectiveness and efficiency in mathematics education? Computer \& Education, 75, 173-184. https://doi.org/10.1016/j.compedu.2014.02.012

\section{APPENDIX}

\section{Main Items of the Questionnaire}

\begin{tabular}{llccc}
\hline 1. Please indicate your response to the following statements & & & \\
\hline & $\begin{array}{c}\text { Strongly } \\
\text { Agree }\end{array}$ & $\begin{array}{c}\text { Neither Agree } \\
\text { nor Disagree }\end{array}$ & $\begin{array}{c}\text { Agree } \\
\text { Disagree }\end{array}$ & $\begin{array}{c}\text { Strongly } \\
\text { Disagree }\end{array}$ \\
\hline a. I know how to operate a Graphing calculator & $\square 5$ & $\square 4$ & $\square 3$ & $\square 2$ \\
\hline b. I know how to operate a Tablet/Mobile Device & $\square 5$ & $\square 4$ & $\square 3$ & $\square 1$ \\
\hline c. I know how to operate a Computer/Laptop & $\square 5$ & $\square 4$ & $\square 3$ & $\square 1$ \\
\hline
\end{tabular}

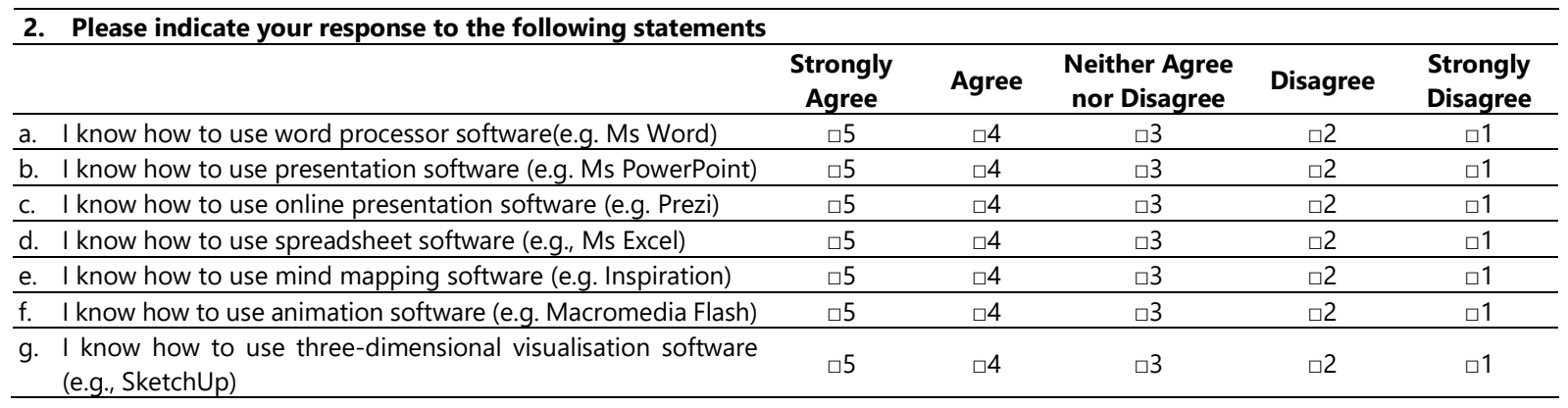


EURASIA J Math Sci and Tech Ed

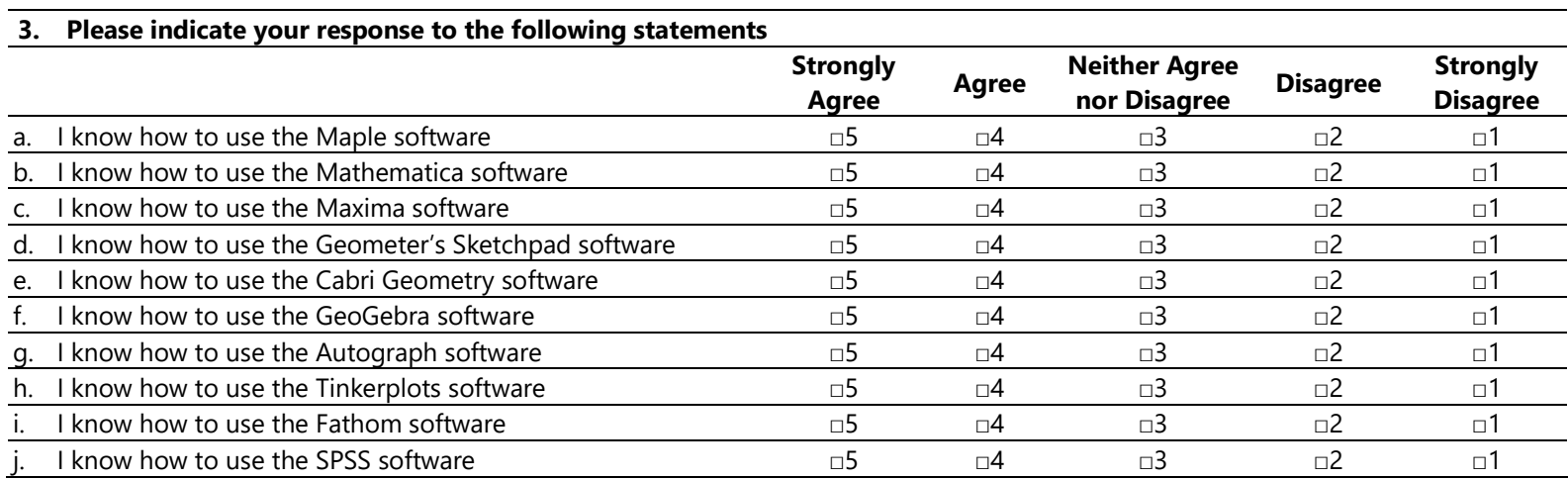

\section{Please indicate your response to the following statements}

\begin{tabular}{|c|c|c|c|c|c|}
\hline 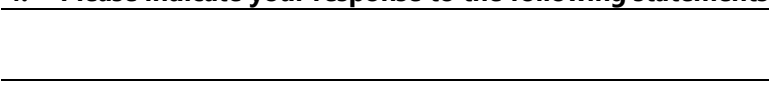 & $\begin{array}{l}\text { Strongly } \\
\text { Agree }\end{array}$ & Agree & $\begin{array}{c}\text { Neither Agree } \\
\text { nor Disagree }\end{array}$ & Disagree & $\begin{array}{l}\text { Strongly } \\
\text { Disagree }\end{array}$ \\
\hline $\begin{array}{l}\text { a. I know how to use Web based applications (e.g., rumah belajar, } \\
\text { m-edukasi, Youtube, and KhanAcademy) in teaching }\end{array}$ & $\square 5$ & $\square 4$ & 口3 & $\square 2$ & 口1 \\
\hline $\begin{array}{l}\text { b. I know how to use Learning management system (e.g. } \\
\text { Blackboard, Moodle) in teaching }\end{array}$ & ๑5 & $\square 4$ & 口3 & $\square 2$ & 1 \\
\hline
\end{tabular}

\section{Please indicate your response to the following statements}

\begin{tabular}{|c|c|c|c|c|c|}
\hline & $\begin{array}{c}\text { Strongly } \\
\text { Agree }\end{array}$ & Agree & $\begin{array}{c}\text { Neither Agree } \\
\text { nor Disagree }\end{array}$ & Disagree & $\begin{array}{l}\text { Strongly } \\
\text { Disagree }\end{array}$ \\
\hline a. I can use ICT to represent mathematical ideas. & $\square 5$ & $\square 4$ & $\square 3$ & $\square 2$ & $\square 1$ \\
\hline b. I can use ICT to communicate mathematical processes. & $\square 5$ & $\square 4$ & $\square 3$ & $\square 2$ & $\square 1$ \\
\hline c. I can use ICT to solve mathematical problems & $\square 5$ & $\square 4$ & $\square 3$ & $\square 2$ & $\square 1$ \\
\hline d. I can use ICT to explore mathematical ideas & $\square 5$ & $\square 4$ & $\square 3$ & $\square 2$ & $\square 1$ \\
\hline
\end{tabular}

\section{Please indicate your response to the following statements}

\begin{tabular}{|c|c|c|c|c|c|}
\hline & $\begin{array}{l}\text { Strongly } \\
\text { Agree }\end{array}$ & Agree & $\begin{array}{c}\text { Neither Agree } \\
\text { nor Disagree }\end{array}$ & Disagree & $\begin{array}{l}\text { Strongly } \\
\text { Disagree }\end{array}$ \\
\hline a. I can use ICT in teaching by employing direct instruction & $\square 5$ & $\square 4$ & $\square 3$ & $\square 2$ & $\square 1$ \\
\hline b. I can use ICT in teaching by employing inquiry based learning & $\square 5$ & $\square 4$ & $\square 3$ & $\square 2$ & $\square 1$ \\
\hline c. I can use ICT in teaching by employing project based learning & $\square 5$ & $\square 4$ & $\square 3$ & $\square 2$ & 口1 \\
\hline d. I can use ICT in teaching by employing discovery learning & $\square 5$ & $\square 4$ & $\square 3$ & $\square 2$ & $\square 1$ \\
\hline e. I can use ICT in teaching by employing collaborative learning & $\square 5$ & $\square 4$ & 口3 & $\square 2$ & $\square 1$ \\
\hline
\end{tabular}

\section{Please indicate your response to the following statements}

\begin{tabular}{|c|c|c|c|c|c|c|}
\hline & & $\begin{array}{c}\text { Strongly } \\
\text { Agree }\end{array}$ & Agree & $\begin{array}{c}\text { Neither Agree } \\
\text { nor Disagree }\end{array}$ & Disagree & $\begin{array}{l}\text { Strongly } \\
\text { Disagree }\end{array}$ \\
\hline a. & $\begin{array}{l}\text { I can use ICT to teach topics of mathematics that are better } \\
\text { learned when employing specific teaching approaches }\end{array}$ & $\square 5$ & $\square 4$ & $\square 3$ & $\square 2$ & $\square 1$ \\
\hline b. & $\begin{array}{l}\text { I can use strategies that combine mathematical content, ICT } \\
\text { and teaching approaches to support students' understandings } \\
\text { as they are learning mathematics }\end{array}$ & $\square 5$ & $\square 4$ & $\square 3$ & $\square 2$ & $\square 1$ \\
\hline c. & $\begin{array}{l}\text { I can use ICT in teaching that enhances mathematical content } \\
\text { and how it taught }\end{array}$ & $\square 5$ & $\square 4$ & $\square 3$ & $\square 2$ & $\square 1$ \\
\hline & $\begin{array}{l}\text { I can use ICT to incorporate authentic tasks in teaching of } \\
\text { mathematics through project based learning }\end{array}$ & $\square 5$ & $\square 4$ & $\square 3$ & $\square 2$ & $\square 1$ \\
\hline & $\begin{array}{l}\text { I can use ICT to teach students to develop their mathematics } \\
\text { problem solving through inquiry-based learning }\end{array}$ & $\square 5$ & $\square 4$ & $\square 3$ & $\square 2$ & 口1 \\
\hline
\end{tabular}

\section{http://www.ejmste.com}

